\title{
PEMBELAJARAN BERBASIS ONLINE "ZOOM" PADA KESIAPAN BELAJAR MAHASISWA DI MASA PANDEMI COVID-19
}

\author{
Rendika Vhalery $^{1}$, Albertus Maria Setyastanto ${ }^{2}$, Sindi Nur Alfilail ${ }^{3(*)}$ \\ Universitas Indraprasta PGRI, Jakarta, Indonesia ${ }^{123}$ \\ rendikavhalery31@gmail.com ${ }^{1}$, setyastantoalbertus@yahoo.co.id ${ }^{2}$, Sindi.alfilail@gmail.com³
}

$\begin{array}{ll}\text { Received: } & 27 \text { Maret } 2021 \\ \text { Revised: } & \text { 28 Maret } 2021 \\ \text { Accepted: } & \text { 29 Maret } 2021\end{array}$

\begin{abstract}
Dunia saat ini sedang dilanda pandemi Covid-19 atau dikenal dengan coronavirus 2019. Untuk meminimalisir dampak ini, pemerintah menerapkan beberapa kebijakan dan menghimbau masyarakat untuk menerapkan sosial distancing, melakukan lockdown, bekerja dari rumah (Work Frome Home), dan belajar melalui daring atau online. Pembelajaran berbasis online menggunakan aplikasi/software "zoom" diharapkan dapat menjadi alternatif model pembelajaran berbasis online. Pembelajaran berbasis online "zoom" dapat menjadi pendukung kesiapan belajar mahasiswa. Dikarenakan kesiapan belajar mahasiswa selama pandemi covid-19 mengalami penurunan. Oleh sebab itu, penelitian ini bertujuan untuk mengetahui pengaruh pembelajaran berbasis online "zoom" terhadap kesiapan belajar mahasiswa di masa pandemi covid-19. Dengan hipotesis adanya pengaruh pembelajaran berbasis online "zoom" terhadap kesiapan belajar mahasiswa di masa pandemi covid-19. Populasi penelitian adalah mahasiswa Unindra. Sampel sebayak 209 mahasiswa yang mengikuti pembelajaran berbasis online. Penelitian ini menggunakan uji regresi linear sederhana. Hasil penelitian menunjukkan bahwa hipotesis yang diajukan diterima. Artinya, terdapat pengaruh pembelajaran berbasis online "zoom" terhadap kesiapan belajar mahasiswa di masa pandemi covid-19.
\end{abstract}

Keywords: Pembelajaran; Online; Zoom; Kesiapan Belajar; Covid-19

Alfilail, Sindi.alfilail@gmail.com

How to Cite: Vhalery, R., Setyastanto, A. M., \& Alfilail, S. N. (2021). Pembelajaran Berbasis Online "Zoom" Pada Kesiapan Belajar Mahasiswa Di Masa Pandemi Covid-19. Research and Development Journal of Education, 7 (1), 215-225.

\section{INTRODUCTION}

Seperti yang kita ketahui bahwa dunia saat ini sedang dilanda pandemi Covid-19. Negara Indonesia juga termasuk salah satunya dan pemerintah menerapkan beberapa kebijakan dan menghimbau untuk menerapkan sosial distancing, melakukan lockdown, bekerja dari rumah (Work Frome Home), dan belajar melalui daring atau online untuk meminimalisir dampak covid-19. Virus Corona (covid-19) atau coronavirus 2019 yang dikenali dengan severe acute respiratory syndrome coronavirus 2 (SARS-CoV-2) disease (Lai, Shih, Ko, Tang, \& Hsueh, 2020), adalah virus yang menyerang sistem pernapasan manusia (Ausrianti, dkk. 2020). Virus covid-19 dapat menyerang siapa saja, seperti bayi, anak-anak, remaja, dewasa, orang tua, ibu hamil, maupun ibu menyusui (Alodokter, 2020).

Pandemi Covid-19 mempengaruhi segala aspek kehidupan. Terutama dalam dunia pendidikan, sekolah yang biasanya dipenuhi aktivitas pembelajaran secara langsung atau 
bertatap muka menjadi aktivitas pembelajaran secara tidak langsung atau pembelajaran berbasis online. Perubahan ini dilakukan untuk menyesuaikan kondisi pandemi covid-19 dan penyesuaian penggunaan pembelajaran berbasis online di Indonesia. Dengan sistem pembelajaran secara online, seringkali muncul beberapa permasalahan yang dihadapi oleh mahasiswa. Beberapa masalah yang sering dialami mahasiswa seperti materi perkuliahan yang belum selesai disampaikan oleh dosen namun mahasiswa sudah harus mengerjakan tugas nya, ditambah dengan tugas-tugas dari mata kuliah lain yang harus diselesaikan sesuai dengan jatuh tempo yang diberikan oleh masing-masing dosen yang bersangkutan. Kendala yang paling dirasakan adalah susah sinyal, kuota cepat habis dan laptop yang suka hang atau eror menyebabkan keterlambatan dalam mengakses informasi pembelajaran (Rizka, 2020). Bahkan, di media sosial banyak mahasiswa yang mengeluh karena sistem pendidikan pada masa pandemi saat ini. Faktanya, proses pendidikan di Indonesia dewasa ini lebih dominan menggunakan mekanisme tatap muka sehingga membuat mahasiswa belum sempat menyiapkan pembelajaran online dengan baik. Secara sederhana, keluhan seperti ini disebabkan oleh ketidaksiapan belajar pada masa pandemi covid-19.

Kesiapan belajar merupakan situasi diri atau kondisi seseorang (khususnya mahasiswa) yang membuatnya siap untuk memberikan respon/jawaban di dalam pelajaran atau siap menerima pelajaran (Widyaningtyas, 2012). Menurut Mulyani (2013), mahasiswa yang memiliki kesiapan belajar tinggi dapat mempertahankan konsentrasinya sehingga dapat memperoleh prestasi belajar yang tinggi, sedangkan mahasiswa yang memiliki kesiapan belajar rendah agar dapat meningkatkan lagi kesiapan belajarnya. Untuk mengetahui apakah kesiapan belajar mahasiswa unindra tinggi atau rendah, peneliti melakukan studi pendahuluan dengan cara melakukan observasi. Dari hasil observasi diketahui bahwa dari 25 orang mahasiswa; 14 orang atau 56\% mahasiswa memiliki kesiapan belajar yang rendah di masa pandemi, 5 orang atau $20 \%$ mahasiswa memiliki kesiapan belajar sedang, dan 6 orang atau 24\% mahasiswa memiliki kesiapan belajar tinggi. Jadi, dapat disimpulkan bahwa mahasiswa unindra secara rata-rata memiliki kesiapan belajar rendah.

Kesiapan belajar mahasiswa unindra yang rendah dipengaruhi oleh beberapa faktor. Faktor yang paling dominan adalah faktor internal dan faktor eksternal dari mahasiswa itu sendiri. Widyaningtyas (2012) menjelaskan faktor internal ini terdiri dari Kondisi fisik, kondisi mental, kondisi emosional, motivasi intrinsik, memiliki inisiatif kebebasan, ketekunan dalam belajar, tanggung jawab sebagai tantangan atau bukan rintangan, kemampuan disiplin diri, keingintahuan yang tinggi, manajemen waktu dan faktor eksternal terdiri dari keperluan diluar diri mahasiswa itu sendiri untuk mendukung kesiapan belajar mahasiswa. Djamarah (2011:185) menambahkan bahwa fasilitas belajar juga dapat mempengaruhi kegiatan pembelajarannya. Mahasiswa yang memiliki fasilitas belajar yang baik, maka pembelajarannya akan berjalan dengan lancar. Sedangkan mahasiswa yang tanpa dibantu fasilitas yang baik akan mengalami hambatan dalam proses pembelajaran.

Fasilitas belajar merupakan sarana dan prasarana untuk memudahkan dan mempelancar dalam proses pembelajaran (Tsabitah \& Wahyudin, 2016). Sarana dan prasarana pendukung bisa bersifat fisik maupun non-fisik. Salah satunya adalah penggunaan pembelajaran berbasis online untuk memperbaiki kesiapan belajar mahasiswa. Pelaksanaan pembelajaran online membutuhkan media dalam mendistribusikan ilmu pengetahuan dalam proses belajar mengajar agar pembelajaran dapat terlaksana dengan efektif (Ismawati dan Prasetyo, 2020). Pembelajaran yang efektif adalah pembelajaran yang dapat mengoptimalkan sistem informasi dan komunikasi sebagai alat bantu dalam proses pembelajaran (Hanum, 2013). Penerapan pembelajaran online tentunya sangat berbeda dalam model dan metode pembelajarannya, sehingga mau 
tidak mau seorang pendidik harus merubah model dan metodenya menyesuaikan agar proses pembelajaran online bisa efektif dan efisien (Purwanti, 2020).

Salah satu aplikasi atau software yang dapat digunakan dalam pembelajaran online adalah Zoom. Zoom merupakan aplikasi atau software layanan konferensi video atau pertemuan online berbasis cloud yang memiliki fitur-fitur seperti pengiriman pesan grup dan perekaman sesi yang aman (Brahma, 2020). Pemanfaatan aplikasi zoom memiliki peran yang sangat baik dalam proses pembelajaran, terlebih jika dilakukan secara tepat (Hyder et al., 2007). Aplikasi zoom ini juga dapat digunakan selain kepentingan belajar. Terlebih lagi, penggunaan aplikasi ini bisa digunakan di smartphone dan PC atau laptop. Keberlangsungan konferensi video pada zoom ini memerlukan jaringan internet yang stabil sehingga mahasiswa dan dosen harus menggunakan akses internet yang baik agar aplikasi zoom yang digunakan tidak tersendat. Penggunaan pembelajaran berbasis online "zoom" diharapkan dapat menumbuhkan kesiapan belajar mahasiswa walaupun secara tidak langsung. Dan diharapkan dapat meningkatkan kemampuan serta keterampilan mahasiswa. Karena pembelajaran berbasis online "zoom" merupakan terobosan baru dalam dunia pendidikan.

Penelitian tentang aplikasi zoom mungkin sudah pernah diteliti oleh peneliti lainnya. Namun, tidak banyak penelitian yang mengungkapkan pembelajaran berbasis zoom di berbagai keadaan. Selain itu, pembahasan kesiapan belajar mahasiswa di era pandemi covid-19 juga merupakan penelitian yang baru menurut kami. Dikarenakan kondisi yang begitu berbahaya harus mencoba membangun kesiapan belajar yang selama ini dianggap biasa. Oleh sebab itu, peneliti ingin mencoba mengkaji penelitian dengan judul "Pembelajaran Berbasis Online "Zoom" Pada Kesiapan Belajar Mahasiswa Di Masa Pandemi Covid-19". Adapun hipotesis yang diajukan yaitu terdapat pengaruh model pembelajaran online "zoom" pada kesiapan belajar mahasiswa di masa pandemi covid-19. Dengan tujuan untuk mengetahui atau mengkaji pengaruh model pembelajaran berbasis online "zoom" terhadap kesiapan belajar mahasiswa di masa pandemi covid-19.

\section{LITERATURE REVIEW}

\section{Model Pembelajaran Berbasis Online}

Pembelajaran online harus direncanakan dan didesain dengan baik agar efektif. Menurut Dunwill (2016) Pada dasarnya prinsip mengajar pada pembelajaran online sama dengan pada pembelajaran tatap muka, yaitu memperkenalkan konsep dan keterampilan yang harus dipelajari, menuntun mahasiswa untuk melakukan proses belajar, dan memberikan latihan-latihan mandiri yang harus dilakukan oleh mahasiswa. Pembelajaran berbasis online memungkinkan pembelajaran dapat dijadwalkan sesuai kesepakatan antara dosen dan mahasiswa, dan mahasiswa belajar mandiri tanpa harus pergi ke ruang kelas (Mahnun, 2019). Ada dua unsur penting yang harus dimiliki dalam pembelajaran berbasis online yaitu metode pengajaran dan informasi yang memudahkan mahasiswa untuk memahami pelajaran (Clark dan Mayer, 2003; Mahnun, 2018). Pembelajaran berbasis online dilakukan melalui media online menggunakan tulisan, suara, ilustrasi gambar maupun video. Proses pembelajaran yang tidak langsung ini juga dinilai memberikan lebih banyak waktu kepada mahasiswa untuk melakukan refleksi atas proses belajarnya, mengkorelasikan materi pembelajaran dangan pengalamannya sendiri, serta untuk memahami materi yang dipelajarinya (Hrastinski, 2008).

Pembelajaran berbasis online memberikan keleluasaan atau fleksibilitas pada dosen dan mahasiswa untuk menentukan waktu belajarnya sendiri dengan kecepatan belajar yang sesuai kondisi masing-masing (Belawati, 2019). Mahnun (2019) 
mengatakan bahwa pembelajaran online memiliki kelebihan sebagai berikut; 1) Meningkatkan interaksi pembelajaran yang dilakukan secara terpisah dalam konsep dunia maya (online), 2) Mempermudah interaksi pembelajaran dari mana saja dan kapan saja, 3) Memiliki jangkauan yang sangat luas, 4) Mempermudah penyempurnaan dan penyimpanan materi pembelajaran. Pembelajaran berbasis online diperuntukkan untuk membantu dosen mengajar mahasiswa secara objektif dan diperlukan kesiapan belajar agar pembelajaran dapat terlaksana dengan baik.

\section{ZOOM}

Zoom Cloud Meeting atau yang dikenal dengan "Zoom" adalah sebuah aplikasi atau software yang dapat digunakan untuk media komunikasi jarak jauh dengan fitur berupa konferensi video, rapat online, kolaborasi seluler, hingga chating. Dengan bantuan aplikasi/software ini, memungkinkan pengguna untuk mengadakan meeting atau pertemuan tanpa harus berada di ruangan yang sama dengan banyak orang. Ada banyak fitur-fitur Zoom yang bisa di manfaatkan selaras dengan kepentingan pengguna seperti Pertemuan rapat one-on-one, Konferensi rapat grup video, Sharing screen \& Chat, dan Fitur Recording Video Call.

Kelebihan dari aplikasi/software Zoom Cloud Meeting ialah; (1) Kapasitas ruang besar yang mampu menampung banyak pengguna dalam satu sesi konferensi, (2) Terdapat fitur on/off video, (3) Dukungan dalam menampilkan bermacam file kepada pengguna lain, baik moderator, narasumber maupun peserta bisa mencoret-coret presentasi tersebut sehingga akan lebih mempermudah pendalaman materi, (4) Tersedia berbagai fitur menarik seperti record dan menyimpan video selama meeting berlangsung, mencerahkan warna kulit wajah Anda, mengubah background sesuai dengan yang diinginkan, hingga membuat jadwal pertemuan online, (5) Kualitas video yang baik dan penampilan suara yang jelas sehingga memudahkan pemakai saat sedang berkomunikasi, (6) Tersedia di berbagai macam perangkat.

Kekurangan aplikasi/software Zoom Cloud Meeting adalah (1) Tidak tersedia nya bahasa Indonesia, (2) Boros kuota, (3) Kurang aman, karena belakangan ini aplikasi/software zoom malah menyerbarluaskan data sensitif seperti wajah, lokasi pengguna, hingga jam login pengguna.

\section{Kesiapan Belajar}

Kesiapan belajar adalah salah satu kondisi yang harus dimiliki mahasiswa, karena proses belajar yang disertai dengan adanya kesiapan akan memudahkan mahasiswa untuk memahami dan menerima materi yang disampaikan oleh dosen serta dapat mendorong mahasiswa untuk memberikan respon yang positif seperti pertanyaanpertanyaan yang diberikan oleh guru serta memberikan gambaran tentang keterkaitan antara materi yang telah dan akan diajarkan (Windiarti, 2018). Kesiapan belajar mahasiswa memberi dampak positif pada pencapaian kompetensi pembelajaran mata kuliah, semakin tinggi kesiapan belajar mahasiswa, maka akan berdampak pada hasil pencapaian kompetensi pembelajaran (Fatchurrohman, 2011).

Indikator kesiapan belajar adalah kesiapan fisik mahasiswa, kesiapan mental, perlengkapan belajar, dan pengetahuan yang dipelajari (Slameto, 2010). Kesiapan fisik pada indikator ini misalnya penglihatan, pendengaran, kesehatan. Kesiapan mental pada indikator ini berbuhubungan dengan kepercayaan pada diri sendiri, penyesuaian diri. Perlengkapan belajar misalnya buku pelajaran, catatan pelajaran, perlengkapan. Pengetahuan yang telah dipelajari seperti membaca buku pelajaran, membaca berita di media cetak. 


\section{METHODS}

Penelitian ini dilakukan di Unindra (Universitas Indraprasta PGRI Jakarta) pada bulan Januari 2021. Populasi dalam penelitian ini adalah mahasiswa pendidikan ekonomi Universitas Indraprasta PGRI Jakarta yang pernah menggunakan aplikasi Zoom. Teknik pegambilan sampel menggunakan non-probability menggunakan accindetal Sampling yaitu sampel yang menggunakan responden yang dapat ditemuin pada saat melakukan penelitian, atau partisipan yang mau menjadi sampel penelitian. Jumlah partisipan dalam sampel penelitian ini yaitu sebanyak 209 mahasiswa pendidikan ekonomi Universitas Indraprasta PGRI. Teknik pengumpulan data yaitu kuesioner (angket). Teknik analisis data menggunakan bantuan software SPSS 25.0. for windows. Instrument penelitian dapat dilihat pada tabel berikut ini:

Tabel 1.

Instrument Penelitian

\begin{tabular}{ll}
\hline \multicolumn{1}{c}{ Variabel } & \multicolumn{1}{c}{ Indikator } \\
\hline 1. Pembelajaran Berbasis Online & 1. Interaksi dalam pembelajaran \\
& 2. Bahan ajar \\
& 3. Mudah memahami pembelajaran \\
& 4. Waktu belajar yang fleksibel \\
& (Utami dan Cahyono, 2020) \\
2. Kesiapan Belajar & 1. Kesiapan fisik \\
& 2. Kesiapan mental \\
& 3. Perlengakapan belajar \\
& 4. Pengetahuan yang telah dipelajari \\
& (Slameto, 2010:113) \\
\hline
\end{tabular}

Sumber : Peneliti (2021)

\section{RESULTS \& DISCUSSION}

Pada tahap awal dilakukan uji normalitas untuk mengetahui apakah data penelitian bersifat normal atau bersifat tidak normal. Apabila data bersifat normal maka dilakukan uji statistik parametrik dan apabila data bersifat tidak normal maka dilakukan uji statistik non-parametrik. Uji normalitas dalam penelitian ini menggunakan rumus Kolmogorovsmirnov. Adapun ketentuan penggunaan uji normalitas data menggunakan rumus kolmogorov-smirnov berbantuan SPSS 25.0 for windows. Apabila nilai Asymp. Sig. (2tailed) pada kolmogorov-smirnov >0,050 maka data bersifat normal. Apabila nilai Asymp. Sig. (2-tailed) pada kolmogorov-smirnov < 0,050 maka data bersifat tidak normal. Hasil uji normalitas data dapat dilihat pada tabel berikut ini:

Tabel 2.

Uji Normalitas Data

\begin{tabular}{llc}
\hline & & Unstandardized Residual \\
\hline $\mathrm{N}$ & & 209 \\
\hline Normal Parameters ${ }^{\mathrm{a}, \mathrm{b}}$ & Mean & .0000000 \\
\cline { 2 - 3 } & Std. Deviation & 5.28922086 \\
\hline \multirow{2}{*}{ Most Extreme Differences } & Absolute & .045 \\
\cline { 2 - 3 } & Positive & .028 \\
\cline { 2 - 3 } & Negative & -.045 \\
\hline Test Statistic & & .045 \\
\hline Asymp. Sig. (2-tailed) & & .200 \\
\hline
\end{tabular}




\begin{tabular}{cc}
\hline Kesimpulan & Normal \\
\hline Sumber : Data Olahan SPSS 25.0
\end{tabular}

Berdasarkan hasil output SPSS pada tabel 2 diketahui bahwa nilai Asymp. Sig. (2tailed) pada rumus Kolmogorov-Smirnov diatas 0,050. Disimpulkan bahwa data penelitian dari variabel Pembelajaran Berbasis Online dan variabel Kesiapan Belajar bersifat normal. Data dapat dilanjutkan pengujian berikutnya. Pengujian berikutnya yaitu uji homogenitas data.

Uji Homogenitas data digunakan untuk mengetahui apakah data penelitian bersifat homogen / sama atau bersifat tidak homogen / tidak sama. Uji homogenitas pada penelitian ini menggunakan uji Lavene. Adapun ketentuan penggunaan uji homogenitas data menggunakan rumus Lavene berbantuan SPSS 25.0 for windows. Apabila nilai Sig. uji lavene > 0,050 maka data bersifat homogen. Apabila nilai Sig. uji lavene < 0,050 maka data bersifat tidak homogen. Hasil uji homogenitas data dapat dilihat pada tabel berikut ini:

Tabel 3.

Test of Homogeneity of Variances

\begin{tabular}{lccccc}
\hline & Levene Statistic & df1 & df2 & Sig. & Kesimpulan \\
\hline Based on Mean & 1.509 & 24 & 177 & .069 & Homogen \\
\hline Sumber : Data Olahan SPSS 25.0 & & & &
\end{tabular}

Berdasarkan hasil output SPSS pada tabel 3 diketahui bahwa nilai Sig. uji lavene diatas 0,050. Disimpulkan bahwa data penelitian dari variabel pembelajaran berbasis online "zoom" dan variabel kesiapan belajar bersifat homogen. Data dapat dilanjutkan pengujian statistik berikutnya. Pengujian berikutnya untuk mengetahui seberapa besar kontribusi variabel model pembelajaran berbasis online "zoom" terhadap kesiapan belajar mahasiswa. Kontribusi variabel ini dapat dilihat melalui perhitungan $r$ square. Hasil perhitungan $r$ square dapat dilihat pada tabel berikut ini:

Tabel 4.

Estimasi R Square

\begin{tabular}{lc|c|c|c}
\hline Model & R & R Square & Adjusted R Square & Std. Error of the Estimate \\
\hline 1 & $.706^{\text {a }}$ & .498 & .496 & 5.30198 \\
\hline \multicolumn{2}{r}{ Sumber : Data Olahan SPSS 25.0 }
\end{tabular}

Berdasarkan hasil output SPSS pada tabel 4 diketahui bahwa nilai $r$ square yaitu 0,498 atau 49,8\%. Artinya, kontribusi model pembelajaran berbasis online "zoom" pada kesiapan belajar mahasiswa sebesar 49,8\%. Sedangkan 50,2\% merupakan kontribusi dari variabel lain. Untuk mengetahui lebih jelas, selanjutnya dapat dilakukan uji regresi linear sederhana untuk menguji hipotesis yang telah diajukan.

Adapun ketentuan dalam pengambilan keputusan dari uji regresi linear sederhana. Apabila nilai $t_{\text {hitung }}>t_{\text {tabel }}$ maka ada pengaruh pembelajaran berbasis online "zoom" terhadap kesiapan belajar mahasiswa. Apabila nilai $\mathrm{t}_{\text {hitung }}<\mathrm{t}_{\text {tabel }}$ maka tidak ada pengaruh pembelajaran berbasis online "zoom" terhadap kesiapan belajar mahasiswa. Hasil perhitungan regresi linear dapat dilihat pada tabel berikut ini: 
Tabel 5.

Uji Regresi Linear Sederhana

\begin{tabular}{cc|c|c|c|c}
\hline \multicolumn{1}{c}{ Model } & \multicolumn{2}{c}{$\begin{array}{c}\text { Unstandardized } \\
\text { Coefficients }\end{array}$} & $\begin{array}{c}\text { Standardized } \\
\text { Coefficients } \\
\text { Beta }\end{array}$ & t & Sig. \\
& B & Std. Error & Beta & \\
\hline & 19.144 & 2.558 & & 7.485 & .000 \\
\hline $\begin{array}{c}\text { Pembelajaran berbasis online } \\
\text { (Constant) }\end{array}$ & .774 & .054 & .706 & 14.329 & .000 \\
\hline
\end{tabular}

Sumber : Data Olahan SPSS 25.0

Berdasarkan hasil output SPSS pada tabel 4 diketahui bahwa nilai regresi linear sederhana $\mathrm{Y}=\mathrm{a}+\mathrm{bX}$ yaitu $\mathrm{Y}=19,144+0,774 \mathrm{X}$. Untuk nilai $\mathrm{t}_{\text {hitung }}$ didapat hasil 14,329 dengan nilai signifikansi sebesar 0,000 . Sedangkan nilai $t_{\text {tabel }}$ untuk taraf kesalahan sebesar 5\% $(0,05)$ dan $n-2=209-2=207$ didapat hasil $t_{\text {tabel }}$ sebesar 1,972. Berdasarkan ketentuan pengambila keputusan uji hipotesis, nilai $t_{\text {hitung }} 14,329>$ nilai $t_{\text {tabel }} 1,972$. Kesimpulannya adalah terdapat pengaruh pembelajaran berbasis online "zoom" terhadap kesiapan belajar mahasiswa di masa pandemi covid-19.

Hasil penelitian menunjukkan bahwa terdapat pengaruh pembelajaran berbasis online "zoom" terhadap kesiapan belajar mahasiswa di masa pandemi covid-19. Kesiapan belajar yang baik dapat meingkatkan proses pembelajaran yang baik juga, hal ini dapat ditunjang dengan menggunakan model pembelajaran berbasis online via aplikasi atau software zoom sebagai perantara pembelajaran jarak jauh yang memungkinkan semua mahasiswa dapat berinteraksi langsung dengan dosen. Model pembelajaran berbasis online via aplikasi atau software zoom bisa dikatakan sebagai pembelajaran seperti di dalam video online. Menurut Denissa (2016:85) pembelajaran seperti di dalam video sangat membantu dalam proses pembelajaran baik formal maupun non formal. Dosen dan mahasiswa dapat melakukan diskusi dan tanya jawab langsung melalui video pembelajaran secara online.

\section{CONCLUSION}

Berdasarkan hasil penelitian dan pembahasan disimpulkan bahwa nilai regresi linear sederhana yaitu $\mathrm{Y}=19,144+0,774 \mathrm{X}$ dengan keputusan hipotesis diterima bahwa terdapat pengaruh pembelajaran berbasis online "zoom" terhadap kesiapan belajar mahasiswa di masa pandemi covid-19 yang dibuktikan melalui perbandingan antara nilai $\mathrm{t}_{\text {hitung }} 14,329>$ nilai $\mathrm{t}_{\text {tabel }} 1,972$. Model pembelajaran berbasis online "zoom" merupakan alternatif pembelajaran jarak jauh yang dapat meminimalisir rendahnya kesiapan belajar mahasiswa. Hal ini dibuktikan melalui tindakan belajar mahasiswa saat pembelajaran online dilaksankan. Namun, ada beberapa keterbatasan penelitian dalam penelitian ini seperti perilaku mahasiswa selama proses pembelajaran (fokus atau tidak fokus pada materi/dosen), tingkat perhatian mahasiswa selama proses pembelajaran, kejelasan dari materi pembelajaran, atau aktivitas lain (diluar pembelajaran) saat proses pembelajaran berlangsung.

Ada beberapa saran bagi guru/dosen/mahasiswa apabila menggunakan model pembelajaran berbasis online khususnya menggunakan software/aplikasi zoom agar pembelajarannya lancar, yaitu menggunakan koneksi internet yang stabil agar tidak menghambat gambar atau suara, hindari penggunaan alat elektronik di sekitar hp/laptop yang digunakan sebagai penggunaan aplikasi/software ini, penggunaan background 
virtual untuk menghindari tampilan latar belakang video. Beberapa keterbatasan ini tidak dapat diungkapkan dikarenakan saat proses pembelajaran berlangsung, ada beberapa layar mahasiswa yang tidak menunjukkan tanda-tanda keberadaan mereka. Untuk itu, saran untuk penelitian berikutnya adalah mengkaji tentang keterbatasan dari penelitian ini.

\section{REFERENCES}

Amelia, R.W. (2020). Amalan Yang Tetap Mengalir, Menjadi Karyawan Dan Dosen Saat Pandemi Covid-19. Banten: DESANTA MULIAVISITAMA

Ausrianti, R., Andayani, R. P., Surya, D. O., \& Suryani, U. (2020). Edukasi pencegahan penularan Covid 19 serta dukungan kesehatan jiwa dan psikososial pada pengemudi ojek online. Jurnal Peduli Masyarakat, 2(2), 59-64.

Belawati, T. (2019). Pembelajaran online. Jakarta, Universitas Terbuka.

Brahma, I. A. (2020). Penggunaan zoom sebagai pembelajaran berbasis online dalam mata kuliah sosiologi dan antropologi pada mahasiswa PPKN di STKIP Kusumanegara Jakarta. Aksara: Jurnal Ilmu Pendidikan Nonformal, 6(2), 97-102.

Clark dan Mayer. (2003). E-learning and the Science of Instruction. USA: Piffer.

Could Host. (2020, March 31). Retrieved from https://idcloudhost.com/mengenalaplikasi-zoom-cara-install-dan-fitur-fitur-zoom-meeting-lengkap/

Denissa Alfiani, dkk. 2016. Pembelajaran Berbasis Video Untuk Anak Generasi Z.Prosiding Inovasi Pendidikan di Era Big Data dan Aspek Psikologinya .ISSN: 2548-5407. PascaSarjana Universitas Negeri Malang. hal 85-92

Dunwill, E. (2016). Elearning best practices. 6 teaching principles transferred to online.

Fatchurrohman, R. (2011). Pengaruh motivasi berprestasi terhadap kesiapan belajar, pelaksanaan prakerin dan pencapaian kompetensi mata pelajaran produktif. Innovation of Vocational Technology Education, 7(2).

Hair, Jr, J. F. (2015). Essentials of Business Research Methods. In Essentials of Business Research Methods. https://doi.org/10.4324/9781315704562

Halodoc. 2020. Jakarta : media online

Hanum, N. S. (2013). Keefetifan e-learning sebagai media pembelajaran (studi evaluasi model pembelajaran e-learning SMK Telkom Sandhy Putra Purwokerto). Jurnal Pendidikan Vokasi, 3(1), 90-102. https://doi.org/10.21831/jpv.v3i1.1584

Haqien, D., \& Rahman, A. A. (2020). Pemanfaatan Zoom Meeting Untuk Proses Pembelajaran Pada Masa Pandemi Covid-19. SAP (Susunan Artikel Pendidikan), $5(1)$.

Hidayatullah, S., Khouroh, U., Windhyastiti, I., Patalo, R. G., \& Waris, A. (2020). Implementasi Model Kesuksesan Sistem Informasi DeLone And McLean Terhadap Sistem Pembelajaran Berbasis Aplikasi Zoom Di Saat Pandemi Covid-19. Jurnal Teknologi Dan Manajemen Informatika, 6(1), 44-52.

Hrastinski, S. (2008). Asynchronous \& synchronous e-learning. Educause Quartely, 31 (4), pp. 51-55.

Hyder, B. K., Kwinn, A., Miazga, R., Murray, M., \& Brandon, B. (2007). The elearning Guild's Handbook on Synchronous e-Learning. The Elearning Guilduild. https://doi.org/10.1093/bioinformatics/bth173

Indrawan, A. F. (2021). Selama Pandemi Pendapatan Zoom Naik Empat Kali Lipat. VOI. Diakses dari: https://voi.id/olahraga/21630/selama-pandemi-pendapatan-zoomnaik-empat-kali-lipat. Diakses pada 25 Februari 2021, Pukul 20:00 WIB. 
Ismawati, D., \& Prasetyo, I. (2020). Efektivitas Pembelajaran Menggunakan Video Zoom Cloud Meeting pada Anak Usia Dini Era Pandemi Covid-19. Jurnal Obsesi: Jurnal Pendidikan Anak Usia Dini, 5(1), 665-675

Lai, C. C., Shih, T. P., Ko, W. C., Tang, H. J., \& Hsueh, P. R. (2020). Severe acute respiratory syndrome coronavirus 2 (SARS-CoV-2) and coronavirus disease-2019 (COVID-19): The epidemic and the challenges. International journal of antimicrobial agents, 55(3), 105924.

Mahnun, N. (2018). Implementasi pembelajaran online dan optimalisasi pengelolaan pembelajaran berbasis online di Perguruan Tinggi Islam dalam mewujudkan World Class University. IJIEM: Kajian Teori dan Hasil Penelitian Pendidikan, 1(1), 2936.

Mahnun, N. (2019). Optimalisasi Pengelolaan dan Pembelajaran Berbasis Online Pada Lembaga Pendidikan Islam dalam Mewujudkan World Class University. Indonesian Journal Of Islamic Educational Management, 1(1), 29-36.

Mahnun, N. (2019). Optimalisasi Pengelolaan dan Pembelajaran berbasis Online pada Lembaga Pendidikan Islam dalam mewujudkan World Class University. Indonesian Journal of Islamic Educational Management, 1(1), 29-36.

Mulyani, D. (2013). Hubungan kesiapan belajar siswa dengan prestasi belajar. Konselor, 2(1).

Purwanti (2020). DOSEN, MAHASISWA DAN WORK FROM HOME DI MASA PANDEMI COVID - 19. Banten: DESANTA MULIAVISITAMA

Slameto. (2010). Belajar dan faktor-faktor yang mempengaruhinya. Jakarta: Rinekacipta.

Tsabitah, D., \& Wahyudin, A. (2016). Peran Kesiapan Belajar dalam Memediasi Pengaruh Kesiapan Belajar dan Fasilitas Belajar Terhadap Hasil Belajar Akuntansi. Economic Education Analysis Journal, 5(1).

Utami, Y. P., \& Cahyono, D. A. D. (2020). Study at Home: Analisis Kesulitan Belajar Matematika Pada Proses Pembelajaran Daring. Jurnal Ilmiah Matematika Realistik, 1(1), 20-26.

Widiarti, E. (2018). Pengaruh Motivasi Belajar dan Kesiapan Belajar Siswa terhadap Hasil Belajar Mata Pelajaran Ekonomi Siswa Kelas X Ilmu-Ilmu Sosial di SMA Negeri 2 Banguntapan. Jurnal Pendidikan Ekonomi, 7(4), 298-305.

Widyaningtyas, A. (2012). Peran lingkungan belajar dan kesiapan belajar terhadap prestasi belajar fisika siswa kelas X Sekolah Menengah Atas Negeri 1 Pati. 


\section{LAMPIRAN}

1. Pembelajaran Berbasis Online

\begin{tabular}{|c|c|c|c|c|c|}
\hline No. & Pernyataan & $\begin{array}{c}\text { Pearson } \\
\text { Correlation }\end{array}$ & $\begin{array}{l}\text { Sig. (2- } \\
\text { tailed) }\end{array}$ & Validitas & Reliabilitas \\
\hline 1. & $\begin{array}{l}\text { Saya aktif bertanya selama } \\
\text { pembelajaran online }\end{array}$ & $.567^{* *}$ & 0.000 & Valid & \\
\hline 2. & $\begin{array}{l}\text { Saya aktif memberikan respon } \\
\text { dalam pembelajaran }\end{array}$ & $.690^{* *}$ & 0.000 & Valid & \\
\hline 3. & $\begin{array}{l}\text { Saya aktif membantu menanggapi } \\
\text { materi pembelajaran }\end{array}$ & $.686^{* *}$ & 0.000 & Valid & \\
\hline 4. & $\begin{array}{l}\text { Saya menyiapkan buku catatan } \\
\text { untuk pembelajaran online }\end{array}$ & $.502^{* *}$ & 0.000 & Valid & \\
\hline 5. & $\begin{array}{l}\text { Saya menyiapkan modul bacaan } \\
\text { untuk pembelajaran online }\end{array}$ & $.668^{* *}$ & 0.000 & Valid & \\
\hline 6. & $\begin{array}{l}\text { Saya menggunakan laptop untuk } \\
\text { belajar online melalui Zoom }\end{array}$ & $.404^{* *}$ & 0.000 & Valid & \\
\hline 7. & $\begin{array}{l}\text { Saya menggunakan Handphone } \\
\text { untuk belajar online melalui }\end{array}$ & $.229^{* * *}$ & 0.001 & Valid & \\
\hline 8. & $\begin{array}{l}\text { Zoom mudah memahami } \\
\text { Saya } \\
\text { pembelajaran teori secara online }\end{array}$ & $.569^{* *}$ & 0.000 & Valid & Reliabel \\
\hline 9. & $\begin{array}{l}\text { Saya mudah memahami } \\
\text { pembelajaran praktik secara } \\
\text { online }\end{array}$ & $.536^{*}$ & 0.000 & Valid & \\
\hline 10. & $\begin{array}{l}\text { Saya mudah memahami } \\
\text { pembelajaran menggunakan Zoom } \\
\text { dari pada melalui chat grup }\end{array}$ & $.505^{*}$ & 0.000 & Valid & \\
\hline 11. & $\begin{array}{l}\text { Melakukan kesepakatan } \\
\text { penentuan waktu belajar antara } \\
\text { mahasiswa dan dosen }\end{array}$ & $.573^{*}$ & 0.000 & Valid & \\
\hline 12. & $\begin{array}{l}\text { Memudahkan belajar kapan saja } \\
\text { dan dimana saja }\end{array}$ & $.585^{* *}$ & 0.000 & Valid & \\
\hline 13. & $\begin{array}{l}\text { Waktu tenggang pengerjaan tugas } \\
\text { yang relatif lama }\end{array}$ & $.410^{* *}$ & 0.000 & Valid & \\
\hline
\end{tabular}


2. Kesiapan Belajar

\begin{tabular}{|c|c|c|c|c|c|}
\hline No. & Pernyataan & $\begin{array}{c}\text { Pearson } \\
\text { Correlation }\end{array}$ & $\begin{array}{l}\text { Sig. }(2- \\
\text { tailed) }\end{array}$ & Validitas & Reliabilitas \\
\hline 1. & $\begin{array}{l}\text { Saya dapat mengaktualisasikan diri } \\
\text { saya terhadap pembelajaran }\end{array}$ & .668 & 0.000 & Valid & \\
\hline 2. & $\begin{array}{l}\text { Saya menjaga kesehatan selama } \\
\text { pemebelajaran online }\end{array}$ & .529 & 0.000 & Valid & \\
\hline 3. & $\begin{array}{l}\text { Saya memusatkan perhatian selama } \\
\text { pembelajaran online }\end{array}$ & .553 & 0.000 & Valid & \\
\hline 4. & $\begin{array}{l}\text { Saya menerima setiap masukan } \\
\text { orang lain dalam pembelajaran } \\
\text { online }\end{array}$ & .594 & 0.000 & Valid & \\
\hline 5. & $\begin{array}{l}\text { Saya mensyukuri setiap materi } \\
\text { yang diberikan kepada saya }\end{array}$ & .575 & 0.000 & Valid & \\
\hline 6. & Saya mampu menjawab pertanyaan & .611 & 0.000 & Valid & \\
\hline 7. & $\begin{array}{l}\text { Saya tidak takut salah dalam } \\
\text { menjawab pertanyaan }\end{array}$ & .592 & 0.001 & Valid & \\
\hline 8. & $\begin{array}{l}\text { Saya memanfaatkan perlengkapan } \\
\text { belajar yang dimiliki untuk } \\
\text { pemenuhan } \quad \text { kebutuhan } \\
\text { pembelajaran online dengan baik }\end{array}$ & .669 & 0.000 & Valid & Reliabel \\
\hline 9. & $\begin{array}{l}\text { Saya dapat menggunakan media } \\
\text { pembelajaran seperti Zoom dengan } \\
\text { baik }\end{array}$ & .652 & 0.000 & Valid & \\
\hline 10. & $\begin{array}{lr}\text { Saya menyiapkan } & \text { perlengkapan } \\
\text { belajar online } & \text { sebelum } \\
\text { pembelajaran di mulai } & \end{array}$ & .664 & 0.000 & Valid & \\
\hline 11. & $\begin{array}{l}\text { Saya membaca buku sebelum } \\
\text { pembelajaran online di mulai }\end{array}$ & .652 & 0.000 & Valid & \\
\hline 12. & $\begin{array}{l}\text { Saya mencari tahu tentang materi } \\
\text { yang akan dipelajari }\end{array}$ & .631 & 0.000 & Valid & \\
\hline 13. & $\begin{array}{l}\text { Saya bertanya kepada dosen } \\
\text { tentang materi yang belum di } \\
\text { mengerti }\end{array}$ & .637 & 0.000 & Valid & \\
\hline 14. & $\begin{array}{l}\text { Saya bertanya kepada teman } \\
\text { tentang materi yang belum di } \\
\text { mengerti }\end{array}$ & .441 & 0.000 & Valid & \\
\hline
\end{tabular}

